University of Nebraska - Lincoln

DigitalCommons@University of Nebraska - Lincoln

Faculty Publications, Department of Psychology

Psychology, Department of

2010

Distinct neural mechanisms underlying acute and repeated administration of antipsychotic drugs in rat avoidance conditioning

\author{
Ming Li \\ University of Nebraska-Lincoln, mli2@unl.edu \\ Tao Sun \\ University of Nebraska-Lincoln, tsun2@unl.edu \\ Chen Zhang \\ Shanghai Mental Health Center, PRC \\ Gang Hu \\ Nanjing Medical University, PRC
}

Follow this and additional works at: https://digitalcommons.unl.edu/psychfacpub

Part of the Psychiatry and Psychology Commons

Li, Ming; Sun, Tao; Zhang, Chen; and Hu, Gang, "Distinct neural mechanisms underlying acute and repeated administration of antipsychotic drugs in rat avoidance conditioning" (2010). Faculty Publications, Department of Psychology. 588.

https://digitalcommons.unl.edu/psychfacpub/588

This Article is brought to you for free and open access by the Psychology, Department of at DigitalCommons@University of Nebraska - Lincoln. It has been accepted for inclusion in Faculty Publications, Department of Psychology by an authorized administrator of DigitalCommons@University of Nebraska - Lincoln. 
Published in Psychopharmacology 212:1 (2010), pp. 45-57; doi: 10.1007/s00213-010-1925-5

Copyright ( 2010 Springer-Verlag. Used by permission.

Submitted February 22, 2010; accepted June 15, 2010; published online July 10, 2010.

\title{
Distinct neural mechanisms underlying acute and repeated administration of antipsychotic drugs in rat avoidance conditioning
}

\author{
Ming $\mathrm{Li}^{1}{ }^{1}$ Tao Sun, ${ }^{1,2}$ Chen Zhang, ${ }^{1,3}$ and Gang $\mathrm{Hu}^{2}$ \\ 1. Department of Psychology, University of Nebraska-Lincoln, 238 Burnett Hall, Lincoln, NE 68588, USA \\ 2. Jiangsu Key Laboratory of Neurodegeneration, Department of Pharmacology, Nanjing Medical University, Nanjing, \\ Jiangsu, People's Republic of China \\ 3. Shanghai Mental Health Center, Shanghai Jiaotong University, 600 South Wanping, Xuhui District, Shanghai, People's \\ Republic of China \\ Corresponding author - Ming Li, email mli2@unl.edu
}

\begin{abstract}
Rationale - Acute antipsychotic treatment disrupts conditioned avoidance responding, and repeated treatment induces a sensitization- or tolerance-like effect. However, the neurochemical mechanisms underlying both acute and repeated antipsychotic effects remain to be determined.

Objective - The present study examined the neuroreceptor mechanisms of haloperidol, clozapine, and olanzapine effect in a rat two-way conditioned avoidance model.

Methods - Well-trained Sprague-Dawley rats were administered with haloperidol $(0.05 \mathrm{mg} / \mathrm{kg}$, sc), clozapine $(10.0 \mathrm{mg} /$ $\mathrm{kg}$, sc), or olanzapine $(1.0 \mathrm{mg} / \mathrm{kg}$, sc) together with either saline, quinpirole (a selective dopamine $\mathrm{D}_{2 / 3}$ agonist, $1.0 \mathrm{mg}$ / $\mathrm{kg}$, sc), or 2,5-dimethoxy-4-iodo-amphetamine (DOI; a selective $5-\mathrm{HT}_{2 \mathrm{~A} / 2 \mathrm{C}}$ agonist, $2.5 \mathrm{mg} / \mathrm{kg}, \mathrm{sc}$ ), and their conditioned avoidance responses were tested over 3 days. After 2 days of drug-free retraining, the repeated treatment effect was assessed in a challenge test.

Results - Pretreatment of quinpirole, but not DOI, attenuated the acute haloperidol-induced disruption of avoidance responding and to a lesser extent, olanzapine-induced disruption. In contrast, pretreatment of DOI, but not quinpirole, attenuated the acute effect of clozapine. On the repeated effect, pretreatment of DOI, but not quinpirole, attenuated the potentiated disruption of haloperidol, whereas pretreatment of quinpirole attenuated the potentiated disruption of olanzapine but enhanced the tolerance-like effect of clozapine.

Conclusions - These findings suggest that acute haloperidol and olanzapine disrupt avoidance responding primarily by
\end{abstract}

blocking dopamine $\mathrm{D}_{2}$ receptors, whereas acute clozapine exerts its disruptive effect primarily by blocking the $5-\mathrm{HT}_{2 \mathrm{~A}}$ receptors. The repeated haloperidol effect may be mediated by $5-\mathrm{HT}_{2 \mathrm{~A} / 2 \mathrm{C}}$ blockade-initiated neural processes, whereas the repeated clozapine and olanzapine effect may be mediated by $\mathrm{D}_{2 / 3}$ blockade-initiated neural processes.

Keywords: Haloperidol, Clozapine, Olanzapine, Quinpirole, 2,5-dimethoxy-4-iodo-amphetamine, Repeated antipsychotic treatment, Conditioned avoidance response, Sensitization, Tolerance

\section{Introduction}

The conditioned avoidance response model (CAR) is a fear-motivated instrumental conditioning model which is traditionally used in behavioral pharmacology as a preclinical screen for antipsychotic activity (Bolles 1970; Levis and Brewer 2001; Rescorla and Solomon 1967). In this model, acute treatment of antipsychotic drugs selectively disrupts avoidance responding without altering unconditioned escape response (Arnt 1982; Wadenberg et al. 2001b). Recently, we have expanded the use of this model to identify the behavioral mechanisms of action of antipsychotic drugs ( $\mathrm{Li}$ et al. 2007; Li et al. 2009a,b; Mead and Li 2009) and to examine the anxiolytic property of atypical antipsy- 
chotic drugs (Mead et al. 2008). It is suggested that understanding the nature of the avoidance deficit induced by antipsychotics may shed light on how antipsychotic drugs achieve their clinical efficacy in the treatment of psychosis (Li et al. 2009b).

Although the avoidance disruptive effect of antipsychotic treatment is robust and well-documented, the neuroreceptor basis of this action is less clear. It has also not been determined whether typical and atypical antipsychotics differ in their neurochemical mechanisms in this model (Wadenberg and Hicks 1999). For typical antipsychotics such as haloperidol (HAL), it is generally assumed (but not proven) that they disrupt avoidance behavior by blocking dopamine $\mathrm{D}_{2}$ receptors because they are primarily dopamine $\mathrm{D}_{2}$ antagonists (Dragunow et al. 1990; Seeman et al. 1976). In contrast, atypical antipsychotics (e.g., clozapine, olanzapine) have multiple-receptor binding sites (Meltzer et al. 1989; Miyamoto et al. 2005), making it more difficult to pinpoint their exact neurochemical mechanisms relevant to their CAR effects. Both clozapine (CLZ) and olanzapine (OLZ) possess a much more potent antagonism on the $5-\mathrm{HT}_{2 \mathrm{~A} / 2 \mathrm{C}}$ receptor in addition to relatively weak antagonism on $\mathrm{D}_{2}$ receptor (Meltzer et al. 2003). It is thus possible that their disruptive effect on CAR could be attributed to their action on $\mathrm{D}_{2}$ receptor alone (Kapur and Seeman 2001; Wadenberg et al. $2001 b$ ) or its dual action on both $5-\mathrm{HT}_{2 \mathrm{~A} / 2 \mathrm{C}}$ and $\mathrm{D}_{2}$ receptor (Meltzer et al. 1989) or even effects on other receptors (e.g. $\mathrm{D}_{1}, \mathrm{D}_{4}, 5-\mathrm{HT}_{1 \mathrm{~A}}$ ).

In the present study, we took a pharmacological approach to delineate the neuroreceptor mechanisms of HAL, CLZ, and OLZ in a two-way CAR model. We examined how the avoidance disruptive effect of these drugs was affected by pretreatments of quinpirole (QUI), a selective $\mathrm{D}_{2} / \mathrm{D}_{3}$ dopaminergic receptor agonist and/or 2,5-dimethoxy-4-iodo-amphetamine (DOI), a selective $5-\mathrm{HT}_{2 \mathrm{~A} / 2 \mathrm{C}}$ serotonergic receptor agonist. We recently applied a similar approach in a rat maternal behavior model and found that pretreatment of QUI, but not DOI, dose-dependently reversed the HAL-induced disruptions on active maternal responses, whereas pretreatment of DOI, but not QUI, dose-dependently reversed the CLZ-induced disruptions (Zhao and Li 2009). Based on these findings and the receptor binding profiles of each antipsychotic (Miyamoto et al. 2005), we hypothesized that QUI, but not DOI, is able to attenuate the HAL-induced disruption on CAR and may also be effective in alleviating the OLZ-induced disruption to some extent. In contrast, DOI, but not QUI, is able to attenuate the CLZ-induced disruption on CAR and may also be effective in alleviating the OLZ-induced disruption to some extent. One additional experiment addressed the specificity of the reversal effects of QUI and DOI on avoidance responding and its relation to their psychomotor stimulating effects.
In our previous studies (Li et al. 2007, 2009a,b; Mead and Li 2009), we found that repeated antipsychotic treatment can produce a long-term change in its disruptive effect on avoidance responding. For example, rats previously treated with HAL and OLZ made significantly less avoidances than those who were treated with these drugs for the first time (Mead and Li 2009). This finding indicates that repeated antipsychotic treatment may induce a sensitization-like effect. However, we know almost nothing about the neuroreceptor mechanisms underlying this repeated drug effect in the avoidance conditioning model. In the present study, we also examined how this long-term repeated effect was affected by pretreatments of QUI and DOI to potentially elucidate its mechanisms.

\section{Materials and methods}

\section{Animals}

Male Sprague-Dawley rats (226-250 g upon arrival, Charles River, Portage, MI) were housed two per cage, in $48.3 \times 26.7 \times 20.3 \mathrm{~cm}$ transparent polycarbonate cages under 12-h light/dark conditions (light on between 6:30 a.m. and 6:30 p.m.). Room temperature was maintained at $22 \pm 1^{\circ}$ with a relative humidity of 55$60 \%$. Food and water were available ad libitum. Animals were allowed at least 1 week of habituation to the animal facility before being used in experiments. All procedures were approved by the Institutional Animal Care and Use Committee at the University of Nebraska-Lincoln.

\section{Two-way avoidance conditioning apparatus}

Eight identical two-way shuttle boxes custom designed and manufactured by Med Associates (St. Albans, VT) were used. Each box was housed in a ventilated, sound-insulated isolation cubicle $(96.52 \mathrm{~cm} \mathrm{~W} \times 35.56 \mathrm{~cm} \mathrm{D} \times 63.5 \mathrm{~cm} \mathrm{H})$. Each box was $64 \mathrm{~cm}$ long, $30 \mathrm{~cm}$ high (from grid floor), and $24 \mathrm{~cm}$ wide, and was divided into two equal-sized compartments by a partition with an arch style doorway $(15 \mathrm{~cm}$ high $\times 9 \mathrm{~cm}$ wide at base). A barrier $(4 \mathrm{~cm}$ high) was placed between the two compartments, so the rats had to jump from one compartment to the other. The grid floor consisted of 40 stainless-steel rods with a diameter of $0.48 \mathrm{~cm}$, spaced $1.6 \mathrm{~cm}$ apart center to center, through which a scrambled footshock (US, $0.8 \mathrm{~mA}$, maximum duration: $5 \mathrm{~s}$ ) was delivered by a constant current shock generator (Model ENV-410B) and scrambler (Model ENV-412). The rat location, motor activity (photobeam breaks), and crossings between compartments were monitored by a set of 16 photobeams (ENV-256-8P) af- 
fixed at the bottom of the box $(3.5 \mathrm{~cm}$ above the grid floor). Illumination was provided by two houselights mounted at the top of each compartment. The CS (i.e., $76 \mathrm{~dB}$ white noise) was produced by a speaker (ENV 224 AMX) mounted on the ceiling of the cubicle, centered above the shuttle box. Background noise (approximately $74 \mathrm{~dB}$ ) was provided by a ventilation fan affixed at the top corner of each isolation cubicle. All training and testing procedures were controlled by Med Associates programs running on a computer.

\section{Drugs}

The injection solution of HAL $(5.0 \mathrm{mg} / \mathrm{ml}$ ampoules, Shanghai Xudong Haipu Pharmaceutical Co., Ltd., Shanghai, China) was obtained by mixing drugs with sterile water. CLZ and OLZ (gifts from NIMH drug supply program) were dissolved in $1.0 \%$ glacial acetic acid in distilled water. QUI and DOI (RBISigma, Natick, MA) were dissolved in $0.9 \%$ saline. All drugs were administered subcutaneously in a volume of $1.0 \mathrm{ml} / \mathrm{kg}$ body weight. Choices of drug doses for HAL, CLZ, and OLZ were based on our previous studies showing that at the chosen doses, all three drugs produce a reliable and comparable disruption of avoidance responding ( $\mathrm{Li}$ et al. 2004; Li et al. 2009a,b; Mead and Li 2009), and they give rise to clinical levels of striatal $\mathrm{D}_{2}$ occupancy $(50-80 \%)$ at these doses (Kapur et al. 2003). The doses of QUI and DOI were chosen based on our recent maternal behavior work showing that QUI $1.0 \mathrm{mg} / \mathrm{kg}$ was effective in reversing the HAL-induced disruptions of active maternal behaviors and that DOI $2.5 \mathrm{mg} / \mathrm{kg}$ was effective in reversing the CLZ-induced disruptions of maternal behaviors (Zhao and Li 2009). Previous work also showed that DOI produces maximal behavioral effects between 2 and $3 \mathrm{mg} /$ kg (Granoff and Ashby 1998; Halberstadt et al. 2009; Schreiber et al. 1995).

\section{Experiment 1: Effects of QUI pretreatment on HAL- and CLZ-induced avoidance disruption}

Sixty rats were first habituated to the two-way CAR boxes for 2 days ( $20 \mathrm{~min} /$ day). Then, they were trained for conditioned avoidance responding for ten sessions over a 2-week period. Each session consisted of 30 trials. Every trial started by presenting the white noise (CS) for $10 \mathrm{~s}$, followed by a continuous scrambled footshock $(0.8 \mathrm{~mA}$, US, maximum duration $=5 \mathrm{~s})$ on the grid floor. If a subject moved from one compartment into the other within the $10 \mathrm{~s}$ of CS presentation, it avoided the shock and this shuttling response was recorded as avoidance. If the rat remained in the same compartment for more than $10 \mathrm{~s}$ and made a crossing upon receiving the footshock, this response was recorded as escape. If the rat did not respond during the entire $5 \mathrm{~s}$ presentation of the shock, the trial was terminated and escape failure was recorded. Intertrial intervals varied randomly between 30 and $60 \mathrm{~s}$. The number of avoidance responses was recorded.

At the end of the training session, 46 rats reached the training criterion $(>70 \%$ avoidance in each of the last two sessions. Their averaged number of avoidances on the last training day $($ mean $)=29.17, \mathrm{SE}=0.18$ ). They were first matched on avoidance performance on the last training day (i.e., predrug) to create blocks of rats ( $n=5-6$ rats/block) that were approximately equal in performance. Within each block, they were then randomly assigned to one of five groups: VEH $+\mathrm{VEH}$ $(n=10$, saline + sterile water), VEH $+\operatorname{HAL}(n=9)$, $\mathrm{VEH}+\mathrm{CLZ}(n=9), \mathrm{QUI}+\mathrm{HAL}(n=9)$, and QUI + CLZ $(n=9)$, and repeatedly tested daily under the CS-only (no shock, 30 trials/session) condition for three consecutive days. The CS-only condition was used to control the possible confound of number of shocks received and to exclude any possible relearning effect caused by the presence of the US. During each test, rats were first pretreated with QUI $1.0 \mathrm{mg} / \mathrm{kg}$ (sc) or saline followed by an injection of sterile water, HAL $0.05 \mathrm{mg} /$ $\mathrm{kg}$ (sc) or CLZ $10.0 \mathrm{mg} / \mathrm{kg}$ (sc) 10 min later. Thirty minutes after the second injection, rats were placed in the CAR boxes and tested. One day after the end of the 3rd test, all rats were tested drug-free for one session under the CS-only (no shock) condition and retrained for one session under the CS-US condition to bring their avoidance back to the predrug level. A final drug challenge test was conducted $24 \mathrm{~h}$ after the retraining session to assess the long-term effect of repeated antipsychotic treatment on avoidance. During the test, rats in the VEH + HAL and QUI + HAL groups were injected with HAL $0.025 \mathrm{mg} / \mathrm{kg}$, whereas rats in the VEH + CLZ and QUI + CLZ groups were injected with CLZ $5.0 \mathrm{mg} /$ $\mathrm{kg}$. Half of the $\mathrm{VEH}+\mathrm{VEH}$ rats $(n=5)$ were injected with HAL $0.025 \mathrm{mg} / \mathrm{kg}$ and another half $(n=5)$ were injected with CLZ $5.0 \mathrm{mg} / \mathrm{kg}$. The CS-only test (no US, 30 trials) was conducted $30 \mathrm{~min}$ after the drug injection.

\section{Experiment 2: Effects of DOI pretreatment on HAL- and CLZ-induced avoidance disruption}

The basic procedure was identical to that of experiment 1 with the exception that DOI $(2.5 \mathrm{mg} / \mathrm{kg}$, sc) pretreatment effect was examined. Sixty rats were used, of which 45 reached the training criterion $(>70 \%$ avoidance in each of the last two sessions, mean $=29.16$, $\mathrm{SE}=0.23$ ). Following the group assigning procedure as described in experiment 1 , they were allocated to the following five groups: VEH + VEH (saline + sterile water), VEH + HAL (0.05 mg/kg), VEH + CLZ (10.0 mg/ $\mathrm{kg})$, DOI + HAL, and DOI + CLZ, and were subjected to 
three sessions of drug testing and two sessions of drugfree testing/retraining and a final drug challenge test, following the exact same schedule as described in experiment 1 . During the challenge test, four VEH $+\mathrm{VEH}$ rats were injected with HAL $0.025 \mathrm{mg} / \mathrm{kg}$ and five were injected with CLZ $5.0 \mathrm{mg} / \mathrm{kg}$.

\section{Experiment 3: Effects of QUI and DOI pretreatment on HAL and CLZ suppressive effect on motor activity in the CAR}

This experiment was designed to examine the specificity of the pretreatment effects of QUI and DOI on antipsychotic-induced avoidance disruption. We asked whether the reversal effects could be attributed to the drug's effects on motor activity. The basic procedure was similar to that used in the above experiments except that on the three drug days, rats were only tested for their motor activity in the CAR boxes, not for their avoidances (i.e., no CS or US was presented). Forty-eight rats were trained in ten sessions, of which 34 reached learning criterion $($ mean $=27.88, \mathrm{SE}=0.41)$. Following the group assigning procedure as described in experiment 1 , they were allocated to the following five groups: $\mathrm{VEH}+\mathrm{VEH}(n=10$, saline + sterile water $), \mathrm{VEH}+\mathrm{HAL}$ $(n=6), \mathrm{QUI}+\mathrm{HAL}(n=6), \mathrm{VEH}+\mathrm{CLZ}(n=6)$, and DOI + CLZ $(n=6)$. Over the next 3 days, 30 min after the second injection, they were placed in the CAR boxes and motor activity was recorded for $30 \mathrm{~min}$ (the approximate time required to complete one CAR session). The number of crossings between two compartments was also recorded.

\section{Experiment 4: effects of QUI and DOI pretreatment on OLZ-induced avoidance disruption}

This experiment examined the receptor mechanisms of acute and repeated effects of OLZ. The basic procedure was identical to that of experiments 1 and 2 with the exception that both QUI $(1.0 \mathrm{mg} / \mathrm{kg})$ and DOI $(2.5 \mathrm{mg} / \mathrm{kg})$ pretreatment effects were examined against OLZ (1.0 mg/kg, sc). Sixty rats were trained in ten sessions, of which 42 reached the training criterion $($ mean $=28.60, \mathrm{SE}=0.31)$. Following the group assigning procedure as described in experiment 1 , they were allocated to the following five groups: $\mathrm{VEH}+\mathrm{VEH}(n=8$, saline + sterile water), VEH + OLZ $(n=9), \mathrm{QUI}+\mathrm{OLZ}$ $(n=8)$, DOI + OLZ $(n=8)$, and QUI + DOI + OLZ $(n$ $=9$ ), and were subjected to the three sessions of drug testing and two sessions of drug-free testing/retraining and a final drug challenge test. During the three drug testing sessions, rats in the QUI + DOI + OLZ group were injected with QUI and DOI first, followed by an injection of OLZ 10 min later. During the drug challenge test, all rats were injected with OLZ at $0.5 \mathrm{mg} / \mathrm{kg}$.

\section{Statistical analysis}

The number of avoidance responses and motor activity data (number of photobeam breaks) were expressed as mean \pm SEM. Data on the three drug test sessions were analyzed using a split-plot analysis of variance (ANOVA) with the between-subjects factor being drug group and the within-subjects factor being test session. To identify group difference on a specific test day, one-way ANOVAs followed by post-hoc Tukey's HSD tests (for more than three groups) were used. Independent samples $t$ tests were used to examine two-group difference in cases where there was a prior research hypothesis.

\section{Results}

Experiment 1: Effects of QUI pretreatment on HAL- and CLZ-induced avoidance disruption

One rat from the QUI + CLZ group died unexpectedly before the retraining and drug challenge test. Its data on these two sessions were not analyzed. As can be seen in Figure 1, HAL and CLZ suppressed avoidance responding on the first drug day and maintained this suppression over the 3 days in comparison to the vehicle treatment. A split-plot ANOVA revealed a main effect of drug treatment $(F(4,41)=50.271$, $P<0.001)$ and a significant treatment $\times$ session interaction $(F(8,82)=4.626, P<0.001)$, but no significant main effect of session $(F(2,82)=2.350, P=0.102)$. One-way ANOVAs followed by post-hoc tests on each drug test day revealed that all drug groups differed significantly from the VEH + VEH group $(P<0.001)$. Post-hoc analysis showed that on the 1st drug day, the QUI + HAL group made significantly more avoidances than the $\mathrm{VEH}+\mathrm{HAL}$ group $(P=0.021)$, whereas the QUI + CLZ group did not differ significantly from the VEH + CLZ group $(P=0.991)$, suggesting that pretreatment of QUI attenuated the HAL-induced disruption of avoidance responding on the 1st day, but did not affect the CLZ-induced disruption. This attenuation effect was no longer present on the subsequent two drug days (all $P>0.10)$.

To detail the time course of the attenuation effect of QUI, we examined the within-session change of avoidance responding across the three ten-trial blocks on day 1 (data not shown). QUI completely reversed the effect of HAL in the 1st block, but lost its effect in the latter blocks (1st block, VEH + VEH vs. QUI + HAL, $P=0.611$; QUI + HAL vs. VEH + HAL, $P=0.010$. Second and third blocks, VEH + VEH vs. QUI + HAL, $P>0.13)$, a finding consistent with QUI's relatively short duration of action (Whitaker and Lindstrom 1987). 
Figure 1. Effects of pretreatment of quinpirole on acute haloperidol and clozapine-induced avoidance disruption. Data are mean (+SEM) numbers of avoidance responses of the five groups of rats on the last CAR training day (predrug), three drug test days (days 1 to 3 ) and two drug-free test days (drug-free CS-only and drug-free retraining). ${ }^{*} P<0.05$ significantly different from the $\mathrm{VEH}+\mathrm{VEH}$ group; \#P $<0.05$ significantly different from the VEH + HAL group.

HAL- and CLZ-treated rats reinstated their avoidance responding in just two sessions when the drug treatments were stopped to a level that was comparable to that of vehicle treatment (Figure 1). On the drug challenge test (Figure 2), rats previously treated with HAL (i.e., VEH + HAL and QUI + HAL) showed much lower avoidance responding than the vehicle rats treated with HAL for the first time. However, an opposite pattern was observed in the CLZ challenge condition: the CLZ-experienced rats (i.e., VEH + CLZ and QUI + CLZ) showed much higher avoidance responding than the vehicle rat treated with CLZ for the first time. One-way ANOVA revealed that under the HAL $(0.025 \mathrm{mg} / \mathrm{kg})$ challenge condition, there was a main effect of group $(F(2,20)=3.638, P=0.045)$, and post-hoc tests showed that the $\mathrm{VEH}+\mathrm{HAL}$ rats made significantly fewer avoidances than the $\mathrm{VEH}+\mathrm{VEH}$ ones (HAL-challenged) $(P=0.039)$. The QUI + HAL group did not differ from the VEH $+\mathrm{VEH}(P=0.116)$ nor the VEH + HAL $(P=0.795)$. Under the CLZ $(5.0 \mathrm{mg} / \mathrm{kg})$ challenge condition, there was a main effect of group $(F(2,19)=6.837, P$ $=0.006$ ), and post-hoc tests showed that the QUI + CLZ group made significantly more avoidances than the $\mathrm{VEH}+\mathrm{VEH}$ (CLZ-challenged) group $(P=0.005)$, but not significantly more than the $\mathrm{VEH}+\mathrm{CLZ}$ group $(P=0.286)$.

Figure 2. Effects of pretreatment of quinpirole on repeated effect of haloperidol and clozapine treatment on avoidance responding. Data are mean (+SEM) numbers of avoidance responses on the challenge test day. Rats that were previously treated with either double vehicles $(n=5)$, vehicle plus haloperidol $(0.05 \mathrm{mg} / \mathrm{kg})$, or quinpirole $(1.0 \mathrm{mg} / \mathrm{kg})$ plus haloperidol $(0.05 \mathrm{mg} / \mathrm{kg})$ were challenged with haloperidol $(0.025 \mathrm{mg} / \mathrm{kg})$. Rats that were previously treated with either double vehicles $(n=5)$, vehicle plus clozapine $(10.0 \mathrm{mg} / \mathrm{kg})$, or quinpirole $(1.0 \mathrm{mg} / \mathrm{kg})$ plus clozapine $(10.0 \mathrm{mg} /$ $\mathrm{kg})$ were challenged with clozapine $(5.0 \mathrm{mg} /$ kg). ${ }^{*} P<0.05$ significantly different from the corresponding VEH + VEH group.

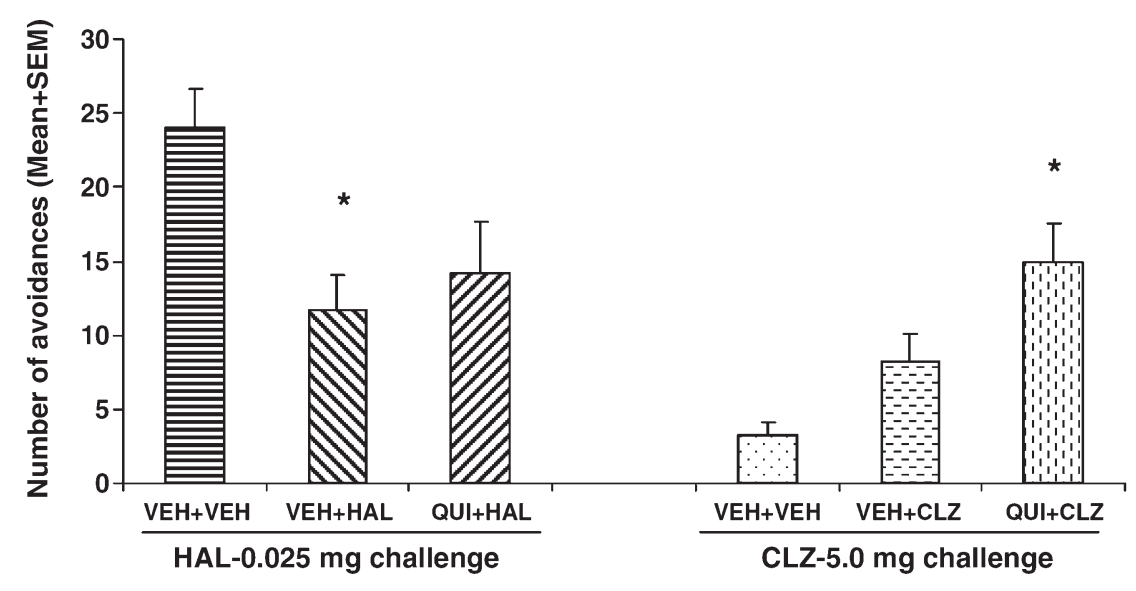


Figure 3. Effects of pretreatment of DOI on acute haloperidol and clozapine-induced avoidance disruption. Data are mean (+SEM) numbers of avoidance responses of the five groups of rats on the last CAR training day (predrug), three drug test days (days 1 to 3) and two drug-free test days (drug-free CS-only and drug-free retraining). ${ }^{*}<0.05$ significantly different from the $\mathrm{VEH}+\mathrm{VEH}$ group; $\# P<0.05$ significantly different from the VEH + CLZ group.

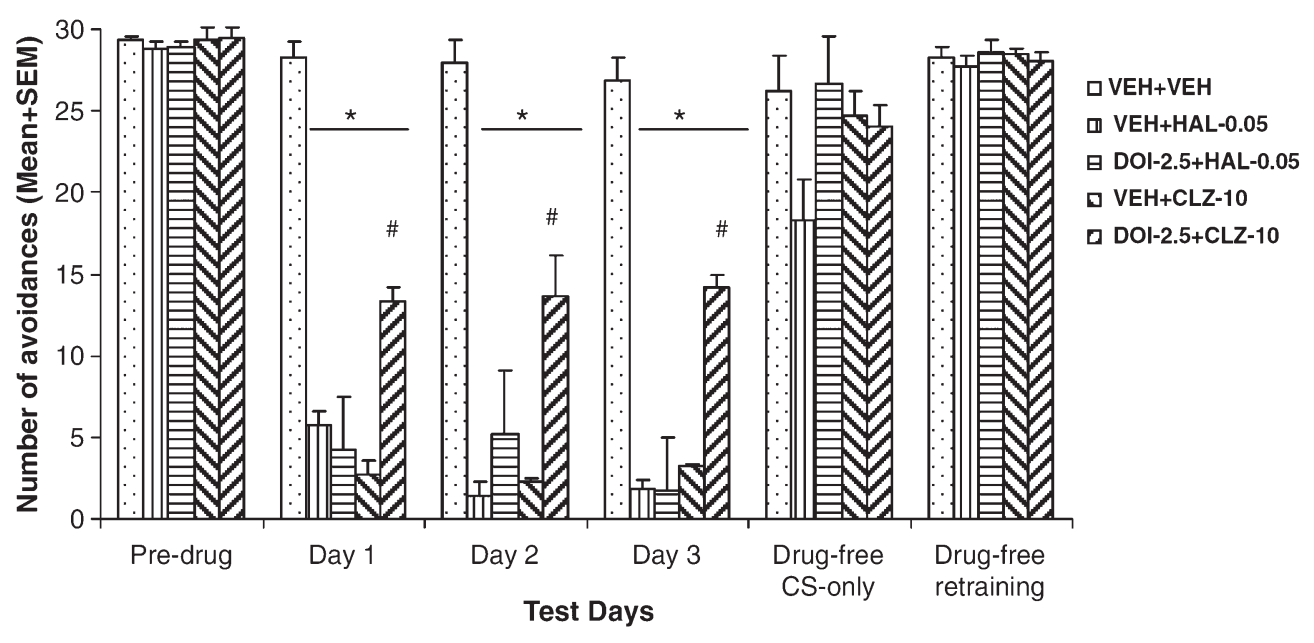

icant level $(F(2,22)=2.103, P=0.148)$. Pretreatment of DOI failed to change the long-term repeated CLZ effect (with there being no significant difference between the $\mathrm{VEH}+\mathrm{CLZ}$ and DOI + CLZ, P > 0.72).

Results from the above experiments suggest that pretreatment of DOI, but not QUI, attenuated the long-term repeated HAL effect on avoidance, whereas pretreatment of QUI, but not DOI, potentiated the long-term repeated CLZ effect. To examine whether this conclusion holds if data from both experiments were combined, we conducted two separate one-way ANOVAs for the combined HAL groups (i.e., VEH + VEH challenged with HAL, VEH + HAL, QUI + HAL, and DOI + HAL) and the combined CLZ groups (i.e., $\mathrm{VEH}+\mathrm{VEH}$ challenged with CLZ, VEH + CLZ, QUI + CLZ, and DOI + CLZ). Results were consistent with the analyses presented above (Figure 5). Under the HAL challenge condition, the VEH + HAL group made significantly fewer

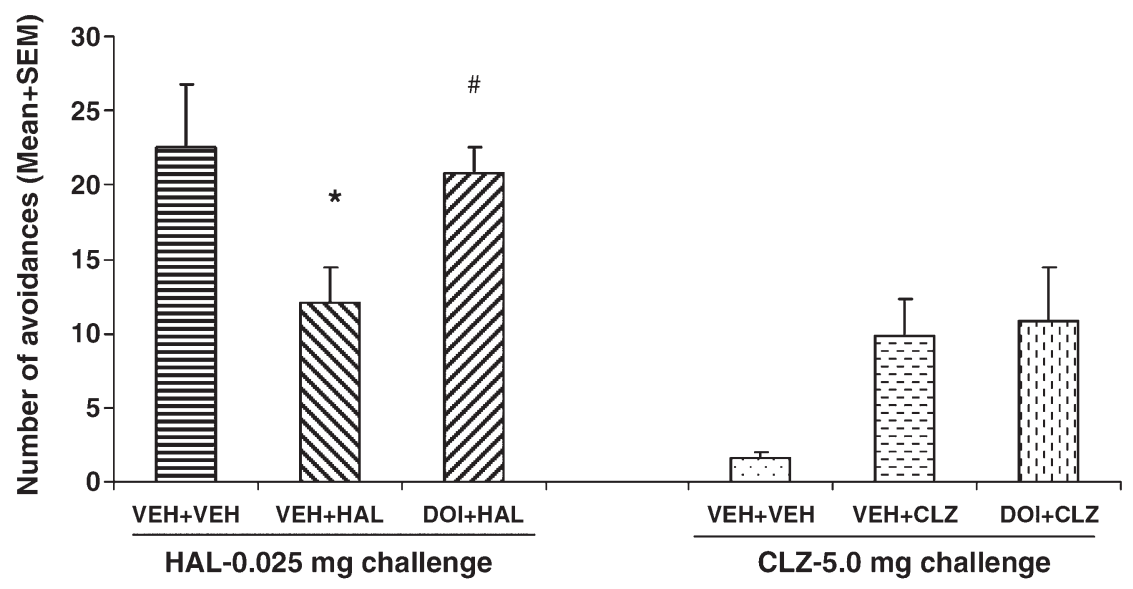

Figure 4. Effects of pretreatment of DOI on repeated effect of haloperidol and clozapine treatment on avoidance responding. Data are mean (+SEM) numbers of avoidance responses on the challenge test day. Rats that were previously treated with either double vehicles $(n=4)$, vehicle plus haloperidol $(0.05 \mathrm{mg} / \mathrm{kg})$, or DOI $(2.5 \mathrm{mg} / \mathrm{kg})$ plus haloperidol $(0.05 \mathrm{mg} / \mathrm{kg})$ were challenged with haloperidol $(0.025 \mathrm{mg} / \mathrm{kg})$. Rats that were previously treated with either double vehicles $(n=5)$, vehicle plus clozapine $(10.0 \mathrm{mg} /$ $\mathrm{kg})$, or DOI $(2.5 \mathrm{mg} / \mathrm{kg})$ plus clozapine $(10.0 \mathrm{mg} / \mathrm{kg})$ were challenged with clozapine $(5.0 \mathrm{mg} / \mathrm{kg})$. ${ }^{*} \mathrm{P}<0.05 \mathrm{significantly} \mathrm{different}$ from the corresponding VEH + VEH group; $\# P<0.05$ significantly different from the VEH + HAL group. 
Figure 5. Combined effects of pretreatment of quinpirole and DOI on repeated effect of haloperidol and clozapine treatment on avoidance responding. Data are mean (+SEM) numbers of avoidance responses on the drug challenge test of the eight groups of rats combined from Experiment 1 and $2 .{ }^{*} P<0.05$ significantly different from the corresponding $\mathrm{VEH}+\mathrm{VEH}$ group; $\# P<0.05$ significantly different from the $\mathrm{VEH}+\mathrm{HAL}$ group.

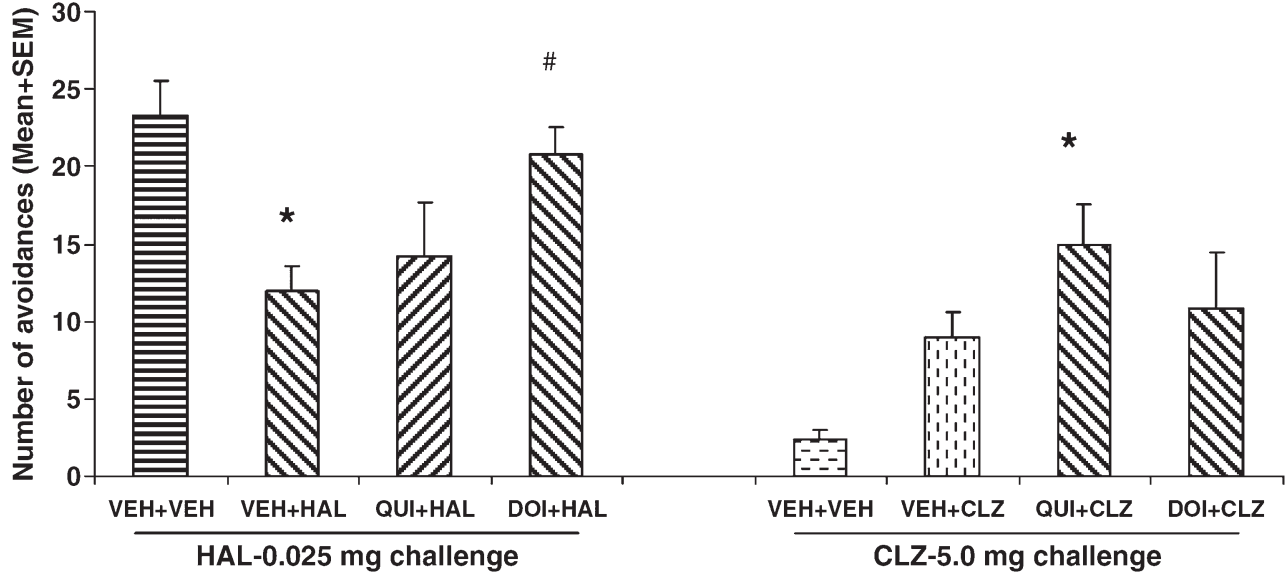

$(P<0.05)$. Also, the QUI + HAL group made significantly more crossings than the $\mathrm{VEH}+\mathrm{HAL}$ group on day $1(P=0.038)$, but not on day $2(P=0.454)$ or three $(P=0.332)$. The DOI + CLZ group made significantly more crossings than the $\mathrm{VEH}+\mathrm{CLZ}$ group only on day $2(P=0.003)$, but not on day $1(P=0.235)$ and day 3 $(P=0.245)$.

\section{Experiment 4: Effects of QUI and DOI pretreatment on OLZ-induced avoidance disruption}

OLZ $1.0 \mathrm{mg} / \mathrm{kg}$ suppressed avoidance responding on the first drug day and progressively enhanced its suppression over the 3-day period (Figure 7). A split-plot ANOVA revealed a main effect of OLZ $(F(4,37)=11.154, P<0.001)$, a main effect of session $(F(2,74)=8.558, P<0.001)$, but no OLZ $\times$ session interaction $(F(8,74)=0.943, P=0.487)$. Individual one-way ANOVA showed that the drug groups made significantly fewer avoidances than the $\mathrm{VEH}+\mathrm{VEH}$ group on each drug day $(P=0.035-0.001)$ except on day 1 , when the QUI + OLZ group $(P=0.262)$ and the DOI + OLZ group $(P=0.053)$ were not significantly different from the $\mathrm{VEH}+\mathrm{VEH}$ group.

The analysis of within-session patterns of avoidance responding on drug days 1 and 2 revealed that the $\mathrm{VEH}+$ OLZ group made significantly fewer avoidances than the $\mathrm{VEH}+\mathrm{VEH}$ group in every block on both days $(P<0.034)$. In contrast, the QUI + OLZ group was only significantly different from the $\mathrm{VEH}+\mathrm{VEH}$ group in the last block on day $2(P=0.033)$. Furthermore, the QUI + OLZ group also made more avoidances than the $\mathrm{VEH}+\mathrm{OLZ}$ group in the 2 nd block on day $2(P=0.019)$, suggesting that pretreatment of QUI significantly attenuated the avoidance disruptive effect of OLZ.

On the drug challenge test (Figure 8), rats previously treated with $\mathrm{VEH}+\mathrm{OLZ}$ made fewer avoidances than the $\mathrm{VEH}+\mathrm{VEH}$ rats. Independent samples $t$ tests showed a significant group difference between the $\mathrm{VEH}+\mathrm{VEH}$ and $\mathrm{VEH}+$ OLZ groups $(t(15)=2.524, P=0.023)$, a finding consistent with our crossings than the $\mathrm{VEH}+\mathrm{VEH}$ group on every test day 
Figure 6. Effects of pretreatment of quinpirole and DOI on haloperidol and clozapine-induced motor suppression without CAR test. a) Motor activity (mean number of photobeam breaks), and b) mean number of crossings of the five groups of rats on the last CAR training day (predrug), three drug test days (days 1 to 3), and two drugfree test days (drug-free CSonly and drug-free retraining). They were either treated subcutaneously with double vehicles, vehicle plus haloperidol $(0.05 \mathrm{mg} / \mathrm{kg})$, or clozapine $(10.0 \mathrm{mg} / \mathrm{kg})$, or quinpirole $(1.0 \mathrm{mg} / \mathrm{kg})$ plus haloperidol $(0.05 \mathrm{mg} / \mathrm{kg})$, or DOI $(2.5 \mathrm{mg} / \mathrm{kg}$ ) plus clozapine $(10.0 \mathrm{mg} / \mathrm{kg}) .{ }^{*} P<0.05$ significantly different from the VEH + VEH group; $\# P<0.05$ significantly different from the VEH + HAL or $\mathrm{VEH}+\mathrm{CLZ}$ group.
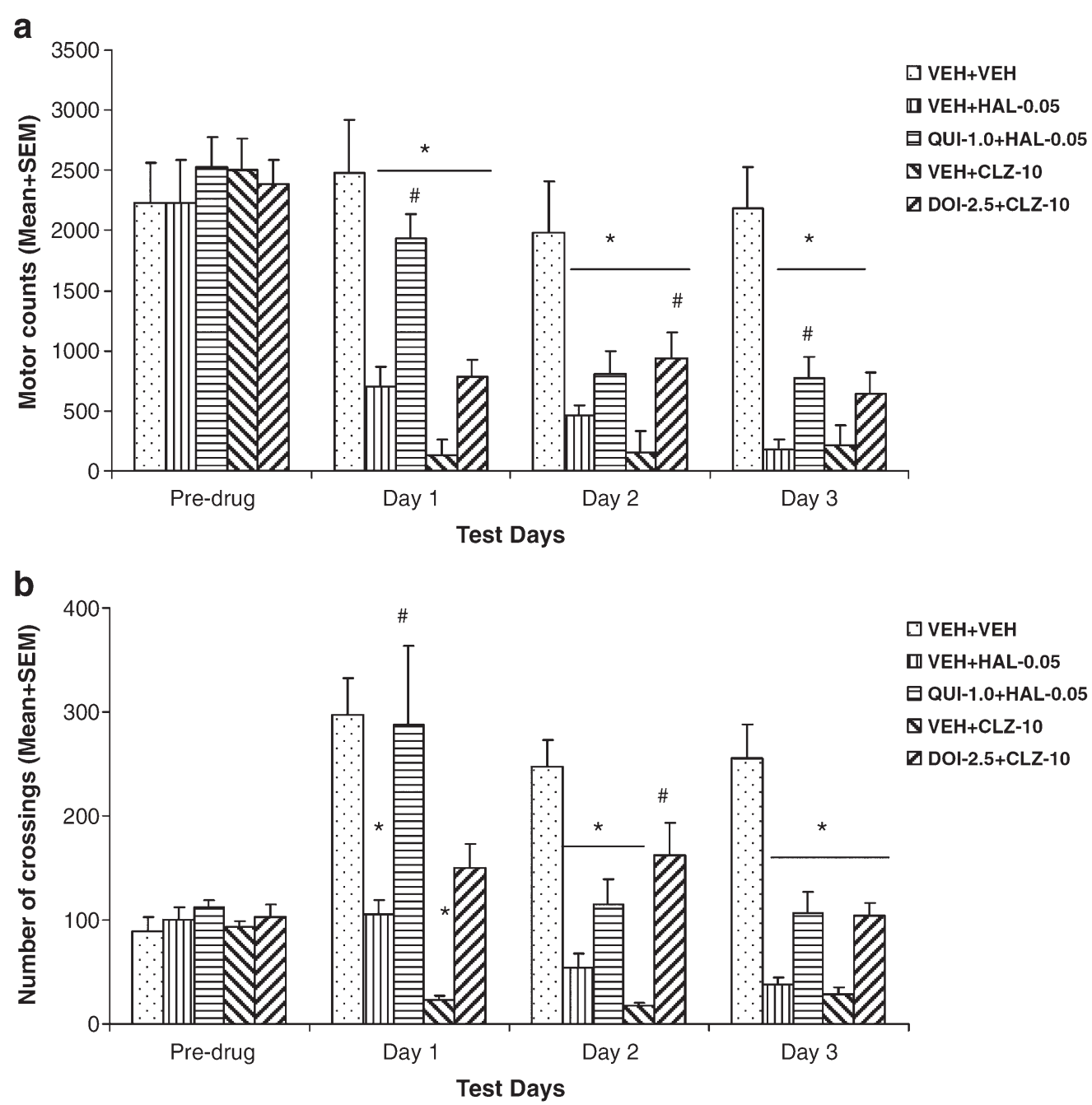

previous work (Li et al. 2009a; Mead and Li 2009). Both QUI and DOI pretreatment attenuated the long-term repeated OLZ effect. However, overall group difference was only marginally significant (overall group difference: $F(4,41)=2.258, P=0.081$ ). To further examine the pretreatment effect of QUI and DOI, we an- alyzed the within-session pattern of avoidance responding on the drug memory test day (data not shown). The only significant group differences were noted between the VEH + OLZ group and one of the two QUI pretreated groups in the 2nd block (oneway ANOVA: $F(4,41)=3.204, P=0.023$; Tukey's
Figure 7. Effects of pretreatment of quinpirole and DOI on acute olanzapine-induced avoidance disruption. Data are mean (+SEM) numbers of avoidance responses of the five groups of rats on the last CAR training day (predrug), three drug test days (days 1 to 3), and two drug-free test days (drug-free CS-only and drugfree retraining). ${ }^{*} P<0.05$ significantly different from the $\mathrm{VEH}+\mathrm{VEH}$ group.

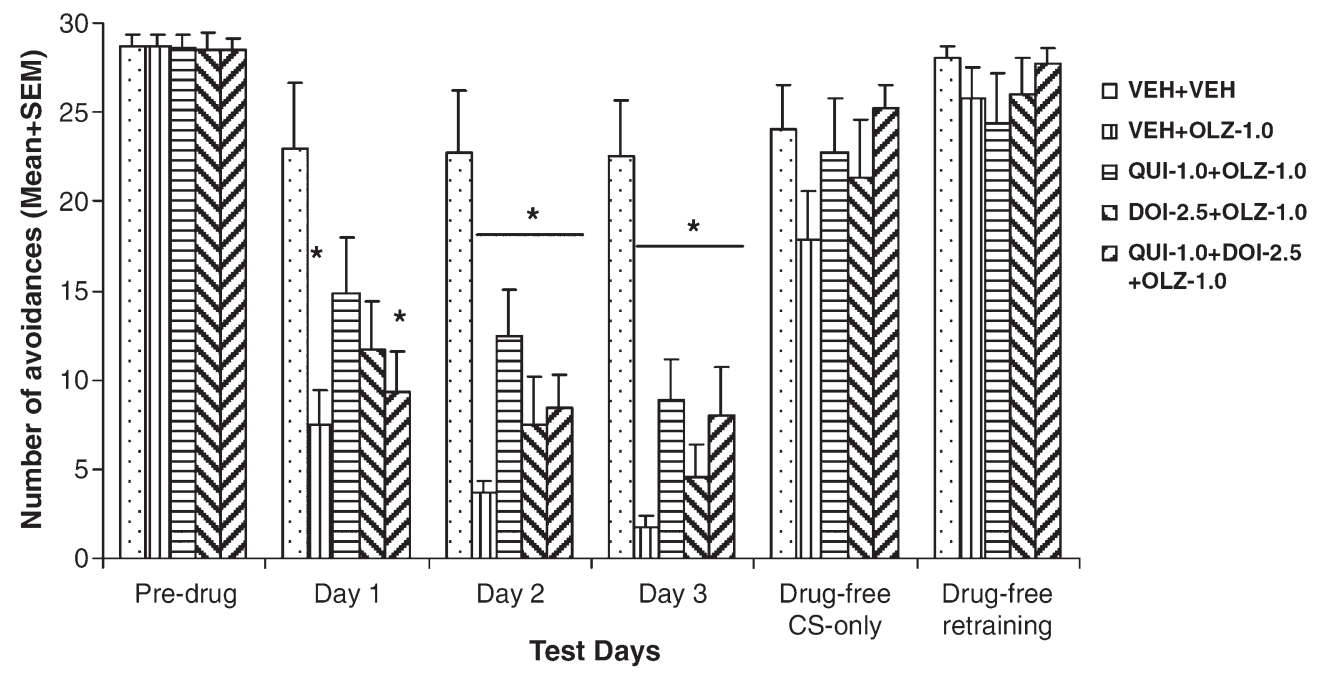


Figure 8. Effects of pretreatment of quinpirole and DOI on repeated effect of olanzapine treatment on avoidance responding. Data are mean (+SEM) numbers of avoidance responses on the drug challenge test. ${ }^{*} P<0.05$ significantly different from the $\mathrm{VEH}+\mathrm{VEH}$ group based on the independent samples $t$ test.

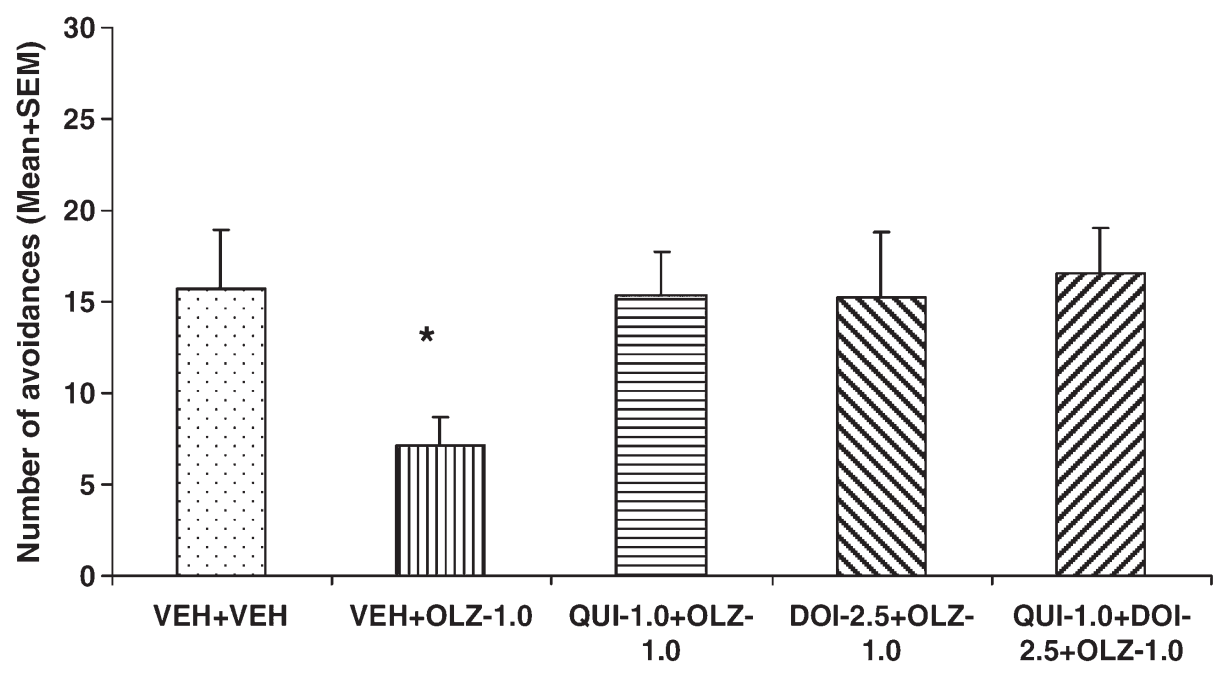

HSD post hoc: $P=0.042$ vs. QUI + OLZ; $P=0.036$ vs. $\mathrm{QUI}+\mathrm{DOI}+\mathrm{OLZ})$, but not to the DOI pretreated group $(P=0.095)$, suggesting that QUI pretreatment is more efficacious than DOI in attenuating the long-term repeated OLZ effect.

\section{Discussion}

The present study demonstrates interesting dissociated dopamine and serotonin receptor mechanisms underlying acute and repeated effects of HAL, CLZ, and OLZ on avoidance responding-a validated behavioral measure of antipsychotic efficacy (Wadenberg and Hicks 1999). Table 1 summarizes the possible receptor mechanisms as identified in the present study.

HAL is a typical antipsychotic with strong dopamine $\mathrm{D}_{2}$ receptor antagonism and low $5-\mathrm{HT}_{2 \mathrm{~A} / 2 \mathrm{C}}$ antagonism (Miyamoto et al. 2005). It is not surprising to see that QUI, a dopamine $\mathrm{D}_{2 / 3}$ agonist, but not DOI, a mixed $5-\mathrm{TH}_{2 \mathrm{~A} / 2 \mathrm{C}}$ agonist, was able to reverse the avoidance disruptive effect of HAL (a simple agonist-antagonist interaction). This finding confirms that HAL disrupts avoidance responding primarily by blocking $\mathrm{D}_{2}$ receptors (Wadenberg et al. 2001b) and is consistent with previous work showing that compounds (e.g., L-dopa) that increase endogenous dopamine activity can reverse antipsychotic-induced disruption of avoidance responding (Davies and Redfern 1974; Seiden and Hanson 1964; Seiden and Peterson 1968). It is also in agreement with other findings showing that QUI and HAL counteract each other in a variety of behavioral tasks, e.g., cat- alepsy (Ninan and Kulkarni 1999), prepulse inhibition (Caine et al. 1995; Wan and Swerdlow 1993), and psychogenic polydipsia (Amato et al. 2008).

CLZ and OLZ are potent $5-\mathrm{HT}_{2 \mathrm{~A} / 2 \mathrm{C}}$ receptor antagonists and relatively weaker dopamine $\mathrm{D}_{2}$ antagonists (Meltzer et al. 2003; Meltzer et al. 1989), but to what extent each receptor action contributes to their disruptive effect on avoidance responding has not been studied. For OLZ, previous studies suggest that blockade of dopamine $\mathrm{D}_{2}$ receptors in the striatum is an integral component (Olsen et al. 2008; Wadenberg et al. 2001b). Our finding that QUI attenuated the disruptive effect of OLZ is consistent with those studies. However, whether OLZ's antagonist action on $5-\mathrm{HT}_{2 \mathrm{~A} / 2 \mathrm{C}}$ receptors also contributes to its avoidance disruption is not known. Based on the evidence that adjunct treatment with selective $5-\mathrm{HT}_{2 \mathrm{~A}}$ receptor antagonists to low doses of dopamine $\mathrm{D}_{2}$ blocking compounds, enhances the antipsychotic-like suppression of CAR in rats (Wadenberg et al. 1996), we can assume that OLZ's 5- $\mathrm{HT}_{2 \mathrm{~A}}$ receptor antagonism may contribute to its disruption on CAR. Given that $5-\mathrm{HT}_{2 \mathrm{C}}$ agonism is known to exert an antipsychoticlike suppression on CAR (Wadenberg and Hicks 1999), we speculate that OLZ's antagonism on $5-\mathrm{HT}_{2 \mathrm{C}}$ receptors may actually lessen its disruptive effect on CAR via $\mathrm{D}_{2}$ and $5-\mathrm{HT}_{2 \mathrm{~A}}$ antagonism mechanisms. Therefore, the lack of DOI reversal effect on OLZ could be explained by DOI's agonist action on $5-\mathrm{HT}_{2 \mathrm{C}}$ which may have masked its reversal effect on OLZ via $5-\mathrm{HT}_{2 \mathrm{~A}}$ receptors. Thus, in the case of OLZ, it appears that its avoidance disruptive effect is mainly mediated by its $\mathrm{D}_{2}$ and $5-\mathrm{HT}_{2 \mathrm{~A}}$ antagonism. Its $5-\mathrm{HT}_{2 \mathrm{C}}$ antagonism may possi-

Table 1. Possible receptor mechanisms underlying acute and repeated effect of haloperidol, clozapine, and olanzapine treatment

\begin{tabular}{llll}
\hline Antipsychotic drugs & Haloperidol & Clozapine & Olanzapine \\
\hline Acute effect & $\mathrm{D}_{2}$ & $5-\mathrm{HT}_{2 \mathrm{~A} / 2 \mathrm{C}}$ & $\mathrm{D}_{2}$ \\
Repeated effect & $5-\mathrm{HT}_{2 \mathrm{~A} / 2 \mathrm{C}}$ & $\mathrm{D}_{2}$ & $\mathrm{D}_{2}$ and $5-\mathrm{HT}_{2 \mathrm{~A} / 2 \mathrm{C}}$ (to a lesser extent) \\
\hline
\end{tabular}


bly lessen its avoidance effect. This notion is also consistent with other evidence showing that $5-\mathrm{HT}_{2 \mathrm{C}}$ antagonism is functionally opposed to $5-\mathrm{HT}_{2 \mathrm{~A}}$ antagonism with regard to antipsychotic action (Meltzer 2002). More work employing more selective $5-\mathrm{HT}_{2 \mathrm{~A}}$ and $5-\mathrm{HT}_{2 \mathrm{C}}$ is needed validate this conclusion.

Based on their receptor binding profiles (Miyamoto et al. 2005) as well as findings from our maternal behavior work (Zhao and Li 2009), we hypothesized that pretreatment of DOI, but not QUI would attenuate acute CLZ-induced disruption on avoidance responding. Results confirm this hypothesis. The lack of an effect of QUI on the acute effect of CLZ is similar to what we observed in our maternal behavior study (Zhao and Li 2009), and suggests that its $D_{2}$ antagonism may not play an important role in its acute effect on avoidance responding. This conclusion is consistent with the observation that although CLZ at $10.0 \mathrm{mg} / \mathrm{kg}$ causes $50 \%$ inhibition of avoidance responding, it only produces $25 \%$ dopamine $\mathrm{D}_{2}$ receptor occupancy (Olsen et al. 2008), far less than what is required to achieve its clinical effect (Kapur et al. 2000). Others also reported that DOI at $10 \mathrm{mg} / \mathrm{kg}$ reversed the avoidance disruptive effect of $10 \mathrm{mg} / \mathrm{kg}$ CLZ (Browning et al. 2005), suggesting the reversal effect of DOI on CLZ is quite robust and is a generalized effect. Because CLZ has dual action on both 5- $\mathrm{HT}_{2 \mathrm{~A}}$ and $5-\mathrm{HT}_{2 \mathrm{C}}$ receptors, and DOI is nonselective for $5-\mathrm{HT}_{2 \mathrm{~A}}$ versus $5-\mathrm{HT}_{2 \mathrm{C}}$ receptors, it is impossible to determine which exact receptor action is responsible for DOI's reversal effect and CLZ's avoidance disruptive effect. There are good reasons to speculate that CLZ may disrupt avoidance responding by primarily antagonizing $5-\mathrm{HT}_{2 \mathrm{~A}}$ receptor, as opposed to $5-\mathrm{HT}_{2 \mathrm{C}}$. Firstly, $5-\mathrm{HT}_{2 \mathrm{C}}$ receptor agonists (e.g., WAY-163909, mCPP, DLSD) are shown to possess a property of suppressing avoidance responding (Grauer et al. 2009; Wadenberg and Hicks 1999). If DOI works by antagonizing CLZ-induced blockade of 5- $\mathrm{HT}_{2 \mathrm{C}}$ receptors, we would expect pretreatment of DOI to potentiate the disruptive of CLZ, as opposed to reverse it. Secondly, selective $5-\mathrm{HT}_{2 \mathrm{C}}$ receptor agonists are generally ineffective in counteracting CLZ. For example, Ro 60-0175 (3 mg/kg), a selective $5-\mathrm{HT}_{2 \mathrm{C}}$ receptor agonist is incapable of attenuating CLZ $(20 \mathrm{mg} / \mathrm{kg})$ - induced dopamine release in rat medial prefrontal cortex, whereas DOI $(2.5 \mathrm{mg} / \mathrm{kg})$ is capable of achieving such an effect (Ichikawa et al. 2001). Thirdly, many behavioral and molecular effects of DOI are found to be mediated by its antagonism on $5-\mathrm{HT}_{2 \mathrm{~A}}$ receptors, not on $5-\mathrm{HT}_{2 \mathrm{C}}$ receptors. For example, DOIinduced effects on locomotor activity, drug discrimination, head-twitch response, and prepulse inhibition (PPI) of acoustic startle are antagonized by $5-\mathrm{HT}_{2 \mathrm{~A}}$-selective antagonist (e.g., M100907) but not by selective $5-\mathrm{HT}_{2 \mathrm{C} / 2 \mathrm{~B}}$ antagonists (e.g. SB 200,646A, SB 206,553, and SER-082) (Halberstadt et al. 2009; Schreiber et al. 1995; Sipes and Geyer 1995, 1997; Smith et al. 2003), and re- peated DOI administration induces significant changes in binding in $5-\mathrm{HT}_{2 \mathrm{~A}}$ receptors but not $5-\mathrm{HT}_{2 \mathrm{C}}$ receptors (Smith et al. 1999).

At the behavioral level, we observed that the patterns of reversal effects of QUI and DOI are fairly consistent with their reversal effects on HAL- and CLZ-induced motor suppression (Figure 6). It is thus tempting to suggest that QUI and DOI attenuated HAL- and CLZ-induced avoidance disruption by increasing motor function. This view may be too simplistic because the increased motor activity and number of inter-compartment crossings may reflect other psychological processes, such as an increase in arousal and attention, or an increase in motivation in responding to stimuli. The motor function view is also difficult in explaining why QUI failed to attenuate the effect of CLZ and DOI failed to attenuate the effects of HAL, as well as why the combination of QUI and DOI also failed to attenuate the effect of OLZ. It is also incompatible with the findings that DOI at this dose range decreases, not increases, motor activity in rats (Elliott et al. 1990; Granoff and Ashby 1998; Hawkins et al. 2008; Hillegaart et al. 1996; Krebs-Thomson and Geyer 1996) and that pretreatment of DOI can reduce neuroleptic-induced catalepsy (presumably increasing motor function) (Wadenberg and Ahlenius 1995). The additional finding that QUI at $1.0 \mathrm{mg} / \mathrm{kg}$ had little effect on avoidance responding by itself, whereas DOI at $2.5 \mathrm{mg} / \mathrm{kg}$ actually suppressed avoidance (see Table 2) is also inconsistent with the general motor function view.

In our previous studies and the present one, we have observed that rats that have been previously treated with HAL and OLZ make significantly fewer avoidance responses than rats treated with these drugs for the first time in a later drug challenge test ( $\mathrm{Li}$ et al. 2007, 2009a; Mead and Li 2009). Interestingly, CLZ appeared to produce an opposite effect: rats previously treated with CLZ tended to make more avoidances than CLZ-naïve rats. This tolerance-like effect of CLZ is not new (Goudie

Table 2. The effect of QUI and DOI treatment alone on avoidance responding

\begin{tabular}{lll}
\hline & Predrug & Test $^{\mathrm{a}}$ \\
\hline QUI-1.0 mg/kg $(n=12)$ & $27.64 \pm 0.897$ & $22.64 \pm 3.082$ \\
DOI-2.5 mg/kg $(n=15)$ & $28.07 \pm 0.679$ & $8.73 \pm 2.205^{*}$ \\
\hline
\end{tabular}

Rats from experiment 3 were first retrained in a 30 -trial CAR session to reacquire avoidance responding. Only those that reached the retraining criterion ( $>70 \%$ avoidance responses) in that retraining session were used in this follow-up test. Rats tested with QUI-1.0 mg/kg consisted of rats that were treated with either vehicle, HAL or QUI + HAL in experiment 3. Rats tested with DOI- $2.5 \mathrm{mg} / \mathrm{kg}$ consisted of rats that were treated with vehicle, CLZ or DOI + CLZ in experiment 3.

* $P<0.001$ significantly different from the predrug condition a. QUI $(1.0 \mathrm{mg} / \mathrm{kg}$, s) and DOI $(2.5 \mathrm{mg} / \mathrm{kg}$, s) were administered $40 \mathrm{~min}$ before a 30 -trial CAR test 
et al. 2007a, b; Villanueva and Porter 1993), as Sanger (1985) also reported that tolerance developed rapidly to the avoidance disruptive effect of CLZ with repeated administration over 4 days. The new findings are on the distinct receptor mechanisms behind the sensitization and tolerance-like effects. Our results indicate that the repeated effect of HAL may be mediated by its action on $5-\mathrm{HT}_{2 \mathrm{~A} / 2 \mathrm{C}}$ receptor system, whereas the repeated effect of OLZ and CLZ may be mediated by their action on $\mathrm{D}_{2 / 3}$ receptor system. Given the fact that HAL is also a $5-\mathrm{HT}_{2 \mathrm{~A}}$ receptor inverse agonist (Weiner et al. 2001), and repeated HAL treatment causes a reduction in $5-\mathrm{HT}_{2 \mathrm{~A}}$ receptor mRNA expression in various limbic regions (Buckland et al. 1997), it is possible that HAL causes a sensitization-like effect in this model by down-regulating $5-\mathrm{HT}_{2 \mathrm{~A}}$ receptor. DOI may decrease this long-term impact of HAL by counteracting its effect on $5-\mathrm{HT}_{2 \mathrm{~A}}$ receptor. This idea is also consistent with the well-known augmentation effect of 5- $\mathrm{HT}_{2 \mathrm{~A}}$ antagonism on HAL. For example, $5-\mathrm{HT}_{2 \mathrm{~A}}$-selective antagonist M100907 is shown to potentiate HAL-induced dopamine release in the medial prefrontal cortex (Bonaccorso et al. 2002), to reduce the reward-attenuating effect of HAL (Benaliouad et al. 2007), and to potentiate the avoidance disruptive effect of HAL (Wadenberg et al. 2001a). The repeated effect of CLZ and OLZ via $\mathrm{D}_{2 / 3}$ receptor systems could be understood in the context of their known long-term effect on $\mathrm{D}_{2 / 3}$ receptors (Atkins et al. 1999; Kapur et al. 2003; Moran-Gates et al. 2006). One important task for future research is to figure out how antipsychotics induce brain changes through these and other receptor systems (e.g., $5-\mathrm{HT}_{1 \mathrm{~A}}, \mathrm{D}_{1}, \mathrm{D}_{4}$, etc.) and how important different receptor mechanisms are to the clinical antipsychotic action of a drug.

Acknowledgments - This study was supported in part by the NARSAD Young Investigator Award (2007-2009), and the NIMH (R21MH079894) grant to Professor Ming Li. We thank Mr. Wei He and Ms. Natashia Swalve for their technical and editorial help. We also thank two anonymous reviewers for their extensive and constructive comments on earlier drafts of this manuscript.

\section{References}

Amato D, Stasi MA, Borsini F, Nencini P (2008) Haloperidol both prevents and reverses quinpirole-induced nonregulatory water intake, a putative animal model of psychogenic polydipsia. Psychopharmacology (Berl) 200:157-165

Arnt J (1982) Pharmacological specificity of conditioned avoidance response inhibition in rats: inhibition by neuroleptics and correlation to dopamine receptor blockade. Acta Pharmacol Toxicol (Copenh) 51:321-329

Atkins JB, Chlan-Fourney J, Nye HE, Hiroi N, Carlezon WA Jr, Nestler EJ (1999) Region-specific induction of deltaFosB by repeated administration of typical versus atypical antipsychotic drugs. Synapse 33:118-128

Benaliouad F, Kapur S, Rompre PP (2007) Blockade of 5-HT2a receptors reduces haloperidol-induced attenuation of reward. Neuropsychopharmacology 32:551-561

Bolles RC (1970) Species-specific defense reactions and avoidance learning. Psychol Rev 77:32-48

Bonaccorso S, Meltzer HY, Li Z, Dai J, Alboszta AR, Ichikawa J (2002) SR46349-B, a 5-HT(2A/2C) receptor antagonist, potentiates haloperidol-induced dopamine release in rat medial prefrontal cortex and nucleus accumbens. Neuropsychopharmacology 27:430-441

Browning JL, Patel T, Brandt PC, Young KA, Holcomb LA, Hicks PB (2005) Clozapine and the mitogen-activated protein kinase signal transduction pathway: implications for antipsychotic actions. Biol Psychiatry 57:617-623

Buckland PR, D'Souza U, Maher NA, McGuffin P (1997) The effects of antipsychotic drugs on the mRNA levels of serotonin 5HT2A and 5HT2C receptors. Brain Res Mol Brain Res 48:45-52

Caine SB, Geyer MA, Swerdlow NR (1995) Effects of D3/D2 dopamine receptor agonists and antagonists on prepulse inhibition of acoustic startle in the rat. Neuropsychopharmacology 12:139-145

Davies JA, Redfern PH (1974) The interaction of dopamine-antagonists and amantadine hydrochloride on the acquisition of the conditioned avoidance response in rats. Neuropharmacology 13:941-948

Dragunow M, Robertson GS, Faull RL, Robertson HA, Jansen K (1990) D2 dopamine receptor antagonists induce fos and related proteins in rat striatal neurons. Neuroscience 37:287-294

Elliott PJ, Walsh DM, Close SP, Higgins GA, Hayes AG (1990) Behavioural effects of serotonin agonists and antagonists in the rat and marmoset. Neuropharmacology 29:949-956

Goudie AJ, Cole JC, Sumnall HR (2007a) Olanzapine and JL13 induce cross-tolerance to the clozapine discriminative stimulus in rats. Behav Pharmacol 18:9-17

Goudie AJ, Cooper GD, Cole JC, Sumnall HR (2007b) Cyproheptadine resembles clozapine in vivo following both acute and chronic administration in rats. J Psychopharmacol 21:179-190

Granoff MI, Ashby CR Jr (1998) The effect of the repeated administration of the compound 3, 4-methylenedioxymethamphetamine on the response of rats to the 5-HT2A, C receptor agonist (+/-)-1-(2, 5-dimethoxy-4-iodophenyl)2-aminopropane (DOI). Neuropsychobiology 37:36-40

Grauer SM, Graf R, Navarra R, Sung A, Logue SF, Stack G, Huselton C, Liu Z, Comery TA, Marquis KL, RosenzweigLipson S (2009) WAY-163909, a 5-HT2C agonist, enhances the preclinical potency of current antipsychotics. Psychopharmacology (Berl) 204:37-48

Halberstadt AL, van der Heijden I, Ruderman MA, Risbrough VB, Gingrich JA, Geyer MA, Powell SB (2009) 5-HT(2A) and 5-HT(2C) receptors exert opposing effects on locomotor activity in mice. Neuropsychopharmacology 34:1958-1967

Hawkins MF, Uzelac SM, Hearn JK, Baumeister AA (2008) Ef- 
fects of selective serotonin2 ligands on behaviors evoked by stress in the rat. Pharmacol Biochem Behav 90:632-639

Hillegaart V, Estival A, Ahlenius S (1996) Evidence for specific involvement of 5-HT1A and 5-HT2A/C receptors in the expression of patterns of spontaneous motor activity of the rat. Eur J Pharmacol 295:155-161

Ichikawa J, Dai J, Meltzer HY (2001) DOI, a 5-HT2A/2C receptor agonist, attenuates clozapine-induced cortical dopamine release. Brain Res 907:151-155

Kapur S, Seeman P (2001) Does fast dissociation from the dopamine $d(2)$ receptor explain the action of atypical antipsychotics?: a new hypothesis. Am J Psychiatry 158:360-369

Kapur S, Wadenberg ML, Remington G (2000) Are animal studies of antipsychotics appropriately dosed? Lessons from the bedside to the bench. Can J Psychiatry 45:241-246

Kapur S, VanderSpek SC, Brownlee BA, Nobrega JN (2003) Antipsychotic dosing in preclinical models is often unrepresentative of the clinical condition: a suggested solution based on in vivo occupancy. J Pharmacol Exp Ther 305:625-631

Krebs-Thomson K, Geyer MA (1996) The role of 5-HT(1A) receptors in the locomotor-suppressant effects of LSD: WAY100635 studies of 8-OH-DPAT, DOI and LSD in rats. Behav Pharmacol 7:551-559

Levis DJ, Brewer KE (2001) The neurotic paradox: attempts by two-factor fear theory and alternative avoidance models to resolve the issues associated with sustained avoidance responding in extinction. In: Mowrer RR, Klein SB (eds) Handbook of contemporary learning theories. Lawrence Erlbaum, Mahwah, pp 561-597

Li M, Davidson P, Budin R, Kapur S, Fleming AS (2004) Effects of typical and atypical antipsychotic drugs on maternal behavior in postpartum female rats. Schizophr Res 70:69-80

Li M, Fletcher PJ, Kapur S (2007) Time course of the antipsychotic effect and the underlying behavioral mechanisms. Neuropsychopharmacology 32:263-272

Li M, He W, Mead A (2009a) An investigation of the behavioral mechanisms of antipsychotic action using a drugdrug conditioning paradigm. Behav Pharmacol 20:184-194

Li M, He W, Mead A (2009b) Olanzapine and risperidone disrupt conditioned avoidance responding in phencyclidinepretreated or amphetamine-pretreated rats by selectively weakening motivational salience of conditioned stimulus. Behav Pharmacol 20:84-98

Mead A, Li M (2009) Avoidance-suppressing effect of antipsychotic drugs is progressively potentiated after repeated administration: an interoceptive drug state mechanism. J Psychopharmacol 24:1045-1053

Mead A, Li M, Kapur S (2008) Clozapine and olanzapine exhibit an intrinsic anxiolytic property in two conditioned fear paradigms: contrast with haloperidol and chlordiazepoxide. Pharmacol Biochem Behav 90:551-562

Meltzer H (2002) Mechanisms of action of atypical antipsychotic drugs. In: Davis KL, Charney D, Coyle JT, Nemeroff $C$ (eds) Neuropsychopharmacology the fifth generation of progress: an official publication of the American College of Neuropsychopharmacology. Lippincott Williams \& Wilkins, Philadelphia
Meltzer HY, Matsubara S, Lee JC (1989) The ratios of serotonin2 and dopamine2 affinities differentiate atypical and typical antipsychotic drugs. Psychopharmacol Bull 25:390-392

Meltzer HY, Li Z, Kaneda Y, Ichikawa J (2003) Serotonin receptors: their key role in drugs to treat schizophrenia. Prog Neuropsychopharmacol Biol Psychiatry 27:1159-1172

Miyamoto S, Duncan GE, Marx CE, Lieberman JA (2005) Treatments for schizophrenia: a critical review of pharmacology and mechanisms of action of antipsychotic drugs. Mol Psychiatry 10:79-104

Moran-Gates T, Gan L, Park YS, Zhang K, Baldessarini RJ, Tarazi FI (2006) Repeated antipsychotic drug exposure in developing rats: dopamine receptor effects. Synapse 59:92-100

Ninan I, Kulkarni SK (1999) Quinpirole, 8-OH-DPAT and ketanserin modulate catalepsy induced by high doses of atypical antipsychotics. Meth Find Exp Clin Pharmacol 21:603-608

Olsen CK, Brennum LT, Kreilgaard M (2008) Using pharmacokinetic-pharmacodynamic modelling as a tool for prediction of therapeutic effective plasma levels of antipsychotics. Eur J Pharmacol 584:318-327

Rescorla RA, Solomon RL (1967) Two-process learning theory: relationships between Pavlovian conditioning and instrumental learning. Psychol Rev 74:151-182

Sanger DJ (1985) The effects of clozapine on shuttle-box avoidance responding in rats: comparisons with haloperidol and chlordiazepoxide. Pharmacol Biochem Behav 23:231-236

Schreiber R, Brocco M, Audinot V, Gobert A, Veiga S, Millan MJ (1995) (1-(2, 5-dimethoxy-4 iodophenyl)2-aminopropane)-induced head-twitches in the rat are mediated by 5-hydroxytryptamine (5-HT) 2A receptors: modulation by novel 5-HT2A/2C antagonists, D1 antagonists and 5-HT1A agonists. J Pharmacol Exp Ther 273:101-112

Seeman P, Lee T, Chau-Wong M, Wong K (1976) Antipsychotic drug doses and neuroleptic/dopamine receptors. Nature 261:717-719

Seiden LS, Hanson LC (1964) Reversal of the reserpine-induced suppression of the conditioned avoidance response in the cat by L-DOPA. Psychopharmacologia 6:239-244

Seiden LS, Peterson DD (1968) Reversal of the reserpine-induced suppression of the conditioned avoidance response by L-dopa: correlation of behavioral and biochemical differences in two strains of mice. J Pharmacol Exp Ther 159:422-428

Sipes TE, Geyer MA (1995) DOI disruption of prepulse inhibition of startle in the rat is mediated by $5-\mathrm{HT}(2 \mathrm{~A})$ and not by 5-HT(2C) receptors. Behav Pharmacol 6:839-842

Sipes TE, Geyer MA (1997) DOI disrupts prepulse inhibition of startle in rats via 5-HT2A receptors in the ventral pallidum. Brain Res 761:97-104

Smith RL, Barrett RJ, Sanders-Bush E (1999) Mechanism of tolerance development to 2, 5-dimethoxy-4-iodoamphetamine in rats: down-regulation of the 5-HT2A, but not 5-HT2C, receptor. Psychopharmacology (Berl) 144:248-254

Smith RL, Barrett RJ, Sanders-Bush E (2003) Discriminative stimulus properties of 1-(2, 5-dimethoxy-4-iodophenyl)- 
2-aminopropane [(+/-)DOI] in C57BL/6 J mice. Psychopharmacology (Berl) 166:61-68

Villanueva HF, Porter JH (1993) Differential tolerance to the behavioral effects of chronic pimozide and clozapine on multiple random interval responding in rats. Behav Pharmacol 4:201-208

Wadenberg ML, Ahlenius S (1995) Antagonism by the 5-HT2A/C receptor agonist DOI of raclopride-induced catalepsy in the rat. Eur J Pharmacol 294:247-251

Wadenberg ML, Hicks PB (1999) The conditioned avoidance response test re-evaluated: is it a sensitive test for the detection of potentially atypical antipsychotics? Neurosci Biobehav Rev 23:851-862

Wadenberg ML, Salmi P, Jimenez P, Svensson T, Ahlenius S (1996) Enhancement of antipsychotic-like properties of the dopamine D2 receptor antagonist, raclopride, by the additional treatment with the 5-HT2 receptor blocking agent, ritanserin, in the rat. Eur Neuropsychopharmacol 6:305-310

Wadenberg MG, Browning JL, Young KA, Hicks PB (2001a) Antagonism at 5-HT(2A) receptors potentiates the effect of haloperidol in a conditioned avoidance response task in rats. Pharmacol Biochem Behav 68:363-370
Wadenberg ML, Soliman A, VanderSpek SC, Kapur S (2001b) Dopamine $\mathrm{D}(2)$ receptor occupancy is a common mechanism underlying animal models of antipsychotics and their clinical effects. Neuropsychopharmacology 25:633-641

Wan FJ, Swerdlow NR (1993) Intra-accumbens infusion of quinpirole impairs sensorimotor gating of acoustic startle in rats. Psychopharmacology (Berl) 113:103-109

Weiner DM, Burstein ES, Nash N, Croston GE, Currier EA, Vanover KE, Harvey SC, Donohue E, Hansen HC, Andersson CM, Spalding TA, Gibson DF, Krebs-Thomson K, Powell SB, Geyer MA, Hacksell U, Brann MR (2001) 5-hydroxytryptamine2A receptor inverse agonists as antipsychotics. J Pharmacol Exp Ther 299:268-276

Whitaker NG, Lindstrom TD (1987) Disposition and biotransformation of quinpirole, a new D-2 dopamine agonist antihypertensive agent, in mice, rats, dogs, and monkeys. Drug Metab Dispos 15:107-113

Zhao C, Li M (2009) The receptor mechanisms underlying the disruptive effects of haloperidol and clozapine on rat maternal behavior: a double dissociation between dopamine $\mathrm{D}(2)$ and 5-HT(2A/2C) receptors. Pharmacol Biochem Behav 93:433-442 